\title{
Teak Yield Regulation in the Natural Forests of the Tharrawaddy Forest Division, Myanmar - 138 Years of the Girth Limit Selection System-
}

\author{
San Win*1 and Minoru Kumazaki*2
}

\begin{abstract}
Attempts to introduce scientific management techniques to forestry in Myanmar began in 1856 with the appointment of Dr. Dietrich Brandis, a German botanist, to manage the Pegu ${ }^{1}$ hill forests of the then Burma. One of Brandis's main management objectives was to ensure a permanent and sustained yield of teak logs from the area's natural forests. He adopted a girth limit selection system in the Tharrawaddy forests of Pegu, and set the minimum exploitable girth limit at 6 feet. Since then the actual yield has fluctuated widely between 1,588 and 9, 250 trees per year, because of changes in the estimates of forest growth rates. Until 1927, the actual rate of harvesting by girdling ${ }^{2}$ was based on estimates of annual yield. However, unstable social and political conditions prevented regular girdling and silvicultural treatment between 1928 and the early 1960s. As social conditions improved from the 1960s, girdling was able to be conducted in some years.

This analysis of the status of the Tharrawaddy forest division's teak stocks uses data from 1912-13, 1982-86 and 1994. It shows that there was poor teak regeneration in low girth classes but an increase in the number of trees in higher girth-classes between 1912 and 1982, and a drastic drop in the growing stock of all girth classes between 1982 and 1994 . The poor regeneration was caused by a lack of adequate silvicultural operations during the 40 to 50 years prior to the 1980s, while illegal logging is the primary cause of the decline in growing stock. Strong action needs to be taken to expand the area of new plantings, to prevent excessive logging, and to increase public participation in forest management. Clear and firm policies to achieve these objectives should become fundamental components of all of Myanmar's future forest management plans.
\end{abstract}

Keyword: Girdling, reserved forests, selection system, teak, working plan

\section{INTRODUCTION}

The teak tree (Tectona grandis) is native to India, Myanmar, Laos and Thailand. Its timber is one of the most valuable in the world. In 1752, the then King of what is now known as Myanmar made all of the nation's teak trees the property of the royal family. The practices of girdling, planting and levying a fee on all teak extracted have been conducted throughout the rule of the Myanmar kings and

\footnotetext{
${ }^{* 1}$ Doctoral Program in Agricultural Science, University of Tsukuba, 1-1-1 Tennodai, Tsukuba, Ibaraki, 305-0006, Japan

${ }^{*}$ Institute of Agriculture and Forestry Science, University of Tsukuba, 1-1-1 Tennodai, Tsukuba, Ibaraki, 305-0006, Japan
}

the British colonial government up to the present day.

Teak timber has not only long been important in Myanmar's economy, but it has also played a critical role in the nation's history. Teak has been one of Myanmar's major foreign exchange earners since the 17th century. Ships made of teak were exported as long ago as the early 17 th century, while substantial volumes of teak were exported by the British in the 19th and 20th centuries (Diokno 1983). Until very recently timber exports accounted for a third of all Myanmar's foreign exchange earnings (Forest DEPARTMENT 1996).

Teak's economic value had other very substantial historical implications for Myanmar. MoREHEAD (1942) states that the acquisition of new, and apparently inexhaustible, supplies of teak of Myanmar was particular interest to the British Government as both English Oak and teak from Malabar and western India, for the Admiralty, 
were running short. Teak timber is said second to non for ship building. In 1885 the nation's king took punitive action against a joint British-Indian trading company for malpractice in the teak timber trade. This action was the excuse used by the British for their third and final annexation war in 1885 that resulted in all of Myanmar coming under British rule.

The economic and political importance of teak to Myanmar means that substantial yield production of teak logs should be given high priority in the nation's forest management. The British colonial powers eventually came to realize this.

After the first British annexation war in 1826, the Tenasserim forests in southern Myanmar were occupied by the British and devastated by uncontrolled logging. The second annexation war in 1852 allowed the British to extend their control into lower Myanmar including the Pegu hill forest areas. This time, however, they decided to manage the forests for sustained yield timber production. The governor-general Dalhousie said: "I hold it to be the duty of the Government of India to preserve the forest resources of Pegu and not to allow them to be wasted as the forest resources of other provinces have been wasted" (BRANDIS 1896).
Dr. Dietrich Brandis, a German botanist, was appointed to manage the newly annexed Pegu forests in 1856 , and he adopted a selection logging system variously called "Brandis's selection system", "girth limit selection system" and "the Burma selection system" for managing teak which was the only marketable timber to abroad at that time. This selection system has been used up to the present day in the Tharrawaddy forest division.

The objectives of this paper are to study the historical development of yield regulation, harvesting and the structure of teak stands in the Tharrawaddy forest division under the selection system, as well as to discuss the future of natural forest management in this division, which is about $125 \mathrm{Km}$ north of Rangoon. The Tharrawaddy forest division contains Minhla, Mokka, Kadinbilin, Konbilin and Thonze reserved forests. These forests cover $85 \%$ of the whole division (see Fig. 1) and are some of Myanmar's main teak producing forests.

\section{BRANDIS'S CONCEPT OF SUSTAINED YIELD}

Yield regulation

From the beginning of his appointment, BRANDIS's

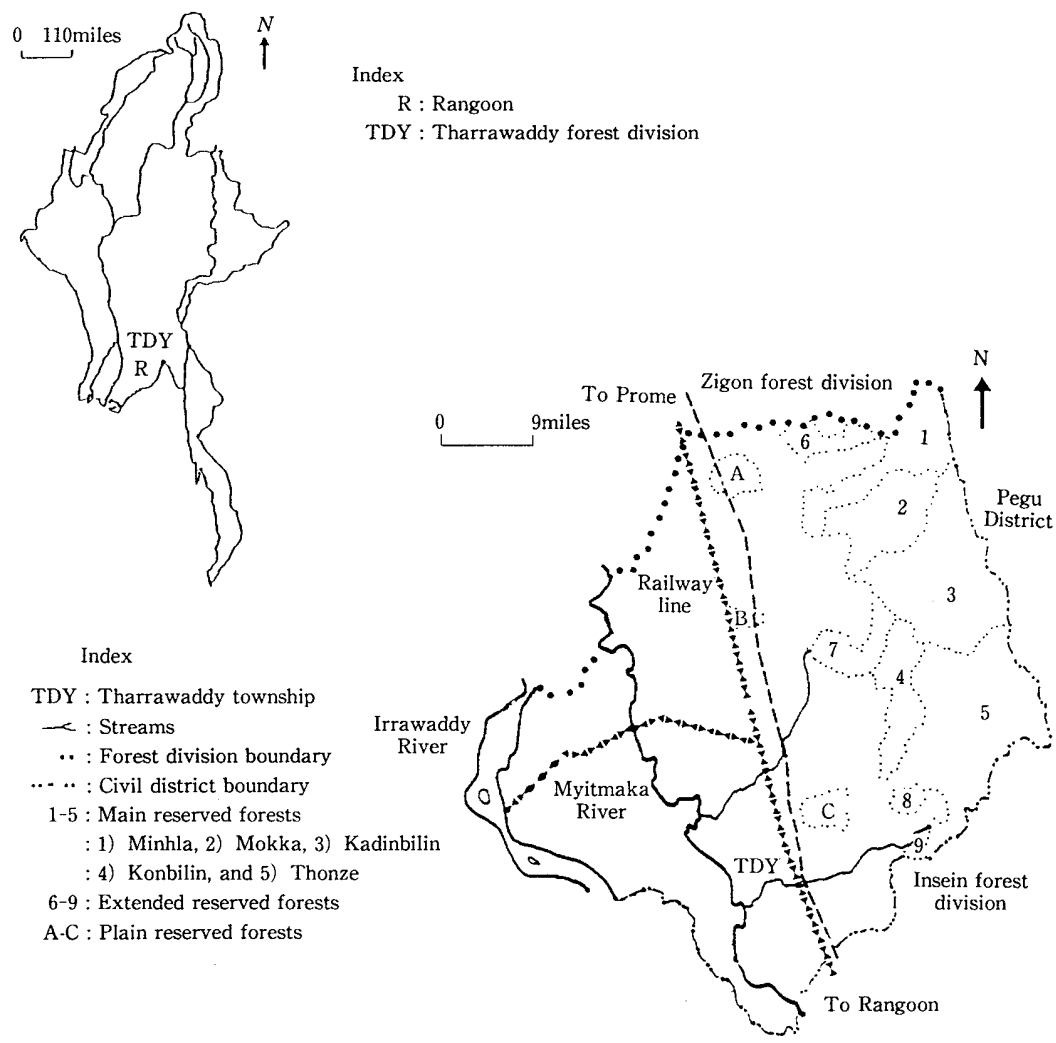

Fig. 1 The location of Tharrawaddy forest division (Southern Tharrawaddy District) in Myanmar 
primary objective was to ensure a permanent and sustained yield of timber from the division's natural forests, arranging the cuttings so as to keep log output well within the forests' productive potential. From line surveys Brandis found that teak trees made up of only 10 to $20 \%$ of the forests (excluding bamboo), and realized that to achieve a sustained yield of teak from such forests, girdling must be conducted sparingly.

BRANDIS set 6 feet as the minimum girth ${ }^{3}$, below which no tree should, as a rule, be felled. Teak trees over this girth were classified as first-class trees, while second-class trees were those between 4 feet 6 inches and 6 feet. Thirdclass trees were between 1 foot 6 inches and 4 feet 6 inches, and fourth-class trees were those smaller than 1 foot 6 inches. Based on survey data on the teak growth in other forests, he estimated that all second-class trees would grow into first-class trees within 24 years, and decided to spread the girdling of the first class trees then standing over a period of 24 years (BRANDIs 1896).

The harvesting rate was to be regulated on the basis of volume, and because teak comprised only a small proportion of the natural forests, Brandis decided to do this by stipulating the number of trees to be cut annually within an area.

\section{Forest Improvement}

Brandis considered that it was important to plant more teak trees to increase the proportion of teak in natural forests. Other activities taken to increase the growth of the teak included, cutting vines at the time of girdling, thinning of immature teak, removing a certain proportion of silviculturally undesirable mature trees, opening up patches of established advanced growth, removal of commercially inferior tree species suppressing teak and its valuable associates (group one species which are also famous species for domestic use) ${ }^{4}$, and cutting of dead and moribund trees. All of these activities were called "improvement fellings" and conducted twice in a rotation of 30 years.

\section{AN OVERVIEW OF THE REGION'S WORKING PLANS}

This section will review the changes in the permitted annual yield and consequently the girdling that occurred under this system since its introduction. The reasons for these changes will be explained in the discussion of seven working plans (see Table 1). The first three plans, those of 1856, 1868 and 1884- were prepared when Brandis was responsible for the division's management. The changes in the permitted annual yields and the actual rate of girdling are shown in Fig. 2 with the number of teak trees girdled presented as ten-year totals (see Table 2).

The 1856 working plan

The first working plan estimated there were a total of 220,000 first class trees in the five main forests of Tharrawaddy (Govt. of Burma 1919). Accordingly, the annual yield was set at 9,250 trees assuming it would take 24 years for the second class trees to mature into first class trees. Actual girdling, which seems to have started in 1861, could only be done in four years, and totalled 12,002 trees. Brandis stated that girdling could not be carried out regularly because of the lack of officers sufficiently competent to conduct supervision. The number of trees harvested between 1856 and 1867 was 55,780 , but this figure includes 43,778 trees that were girdled before Brandis's arrival (Govt. OF BuRMa 1918).

Table 1 The level of teak harvest permitted by different working plans

\begin{tabular}{lcl}
\hline Working plan & ANTPC & Remarks \\
\hline 1856 & 9,250 & $\begin{array}{l}\text { In the first plan R was 24 years. } \\
1868\end{array}$ \\
1884 & 3,588 & $\begin{array}{l}\text { R was 72 years, but } 80 \text { years was used to set the permitted yield. } \\
\text { In this special plan, R was } 38 \text { years. A separate yield was set for each } \\
\text { forest. }\end{array}$ \\
1918 & $\begin{array}{l}\text { Yield was controlled by area. After 1924, the permitted yield was } \\
3,952 \text { trees. }\end{array}$ \\
1928 & 8,190 & $\begin{array}{l}\text { Yield was controlled using the Burmese version of Von Mantel's } \\
\text { formula. } \\
1946-47\end{array}$ \\
$1963-64$ & $\begin{array}{l}\text { Because documents were lost, the permitted yield was based on a } \\
\text { ratio basis. } \\
\text { In this most recent paln, the permitted yield was set using the same } \\
\text { method as in the 1946-47 plan. }\end{array}$ \\
\hline
\end{tabular}

ANTPC: Annual number of trees permitted to be cut

$\mathrm{R}$ : The number of years required for trees to grow from the $2^{\text {nd }}$ class into $1^{\text {st }}$ class 


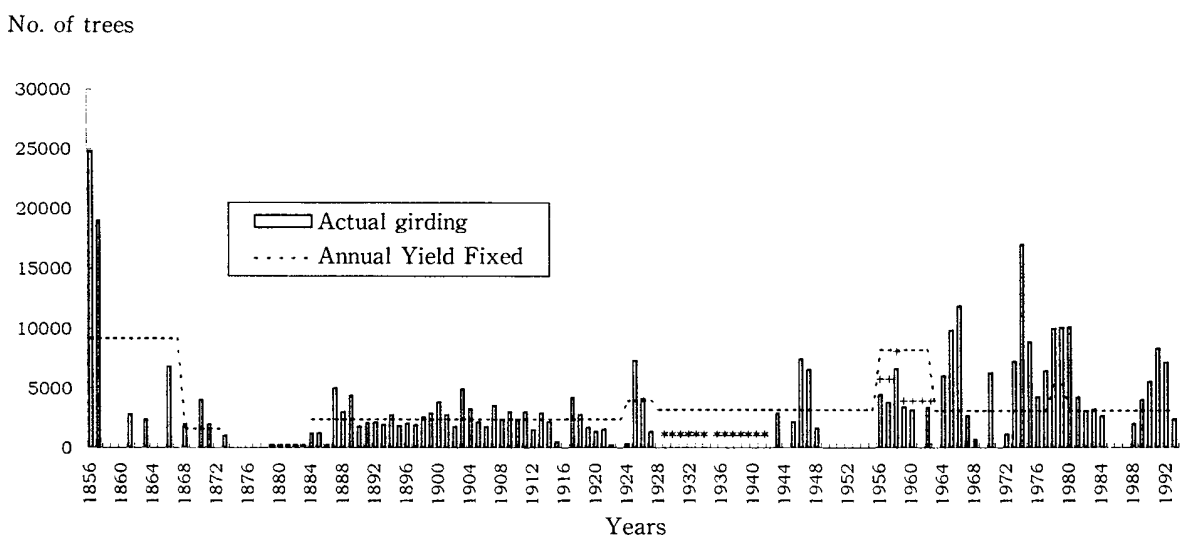

Fig. 2 The annual permitted level of teak harvest and actual removals between 1856 and 1993 Source: Tharrawaddy Working Plans (1918, 1919, 1928, 1946-47, 1963-64, and Forest Department, 199). "*" represents the years when gidling was conducted, but for which no data are available. "+" represents the years for which partial data are available

Table 2 The number of trees girdled in the major forest areas of the Tharrawaddy district-presented as 10 year totals

\begin{tabular}{|c|r|r|r|r|r|r|}
\hline Year/Reserve & Thonze & \multicolumn{1}{|c|}{ Minhla } & Mokka & Kadinbilin & Konbilin & Total \\
\hline $1856-1865$ & 18,979 & 6,290 & 4,839 & 10,541 & 8,325 & 48,974 \\
$1866-1875$ & 4,015 & 4,025 & 1,003 & 5,406 & 1,400 & 15,849 \\
$1876-1885$ & 0 & 2,008 & 1,000 & 402 & 0 & 3,410 \\
$1886-1895$ & 5,816 & 2,289 & 3,039 & 11,579 & 2,377 & 25,100 \\
$1896-1905$ & 9,063 & 3,946 & 2,671 & 11,191 & 1,390 & 28,261 \\
$1906-1915$ & 8,676 & 5,461 & 1,599 & 5,165 & 2,163 & 23,064 \\
$1916-1925$ & 7,646 & 7,366 & 2,145 & 1,783 & 431 & 19,371 \\
$1926-1935$ & 1,060 & 0 & 1,066 & 3,373 & 0 & $15,194^{*}$ \\
$1936-1945$ & 3,567 & 0 & 0 & 1,504 & 0 & $13,381 \#$ \\
$1946-1955$ & 5,461 & 0 & 0 & 9,001 & 1,036 & 15,678 \\
$1956-1965$ & 0 & 7,784 & 4,569 & 12,494 & 0 & $81,631 \&$ \\
$1966-1975$ & & & & & & 55,949 \\
$1976-1985$ & & & & & & \\
$1986-1993$ & & & & & & 4,064 \\
\hline Total & & & & & & \\
\hline
\end{tabular}

Source: Working Plans (1918-19, 1928, 1946-47, 1963-64)

Notes: The numbers of trees girdled in each reserved forest after 1962-63 is unavailable.

“* \#, \&" includes the author's own estimates of yield and they are shown as followns; *9,695 trees between 1926-35, \# 8,310 between 1936-45 and \& 40,852 trees in the period from 1956 to 1965 . There were a total of 15,932 trees girdled in 1964 and 1965, however, it is not known in which reserve (s), these trees were girdled. These estimates are based on the density of the trees girdled in those compartments for which data are available.

The 1868 working plan

Surveys conducted in 1868 showed that the annual yield needed to be changed. The differences between assumptions made in 1856 and those required in 1868 were very serious:

"...the rate of growth assumed in 1856 was too rapid, that of 1868 was much too slow. No less than seventy-two years were supposed to be necessary to bring up a Teak-tree in the forests from a girth of four feet six inches to six feet, against twenty-three years in 1856 . The second class trees having been found to be less numerous than those of the first class, it was decided to 
spread the removal of the latter over a period of eighty years (BRANDIS 1896).

In line with these changes, the number of first-class trees was estimated at 127,000 and the annual yield was set at 1,588 trees. However, it was expected that this plan would expire in 1873 and that the forests would then be managed using special management plans, so girdling was only planned for the following five years. According to BRANDIS (1896), it was hoped that rapid progress would then be made in the selection and demarcation of the forests to be permanently maintained as such, and that when the boundaries of these forests had been laid down, special working plans for each forest district would then be prepared. However, girdling was conducted in only three years, for a total of 9,043 trees, and introduction of the special working plans was delayed until 1884. There was no plan for the eleven years between 1873 and 1884, and only 1,200 trees were girdled.

\section{The 1884 working plan}

This plan introduced new and distinct features. Forests were divided into compartments, and the growing stock in each compartment was estimated separately using data from sample areas. The plan had 2 main points:

1) The kind of treatment to be conducted in reserved forests must be based on the characteristics of each area; and,

2) The reproduction and growth of teak trees must not be impeded, but, if possible, promoted by the removal of girdled trees.

While teak was found to have different growth rates at different localities within the Irrawaddy valley forests which contains Tharrawaddy forests, it was proposed to allow a period of 38 years for second class teak trees to mature into first class trees for those forests. Based on this growth rate, the condition of each reserved forest and an estimated total growing stock of 91,497 trees, the annual yield was fixed at 3,100 trees. According to the 1963-64 working plan, a total of 90,125 trees was girdled up to 1917 , giving an annual average of 2,650 trees.

\section{The 1918 working plan}

The first Burma forest conference in 1910 decided to introduce a uniform system of logging and management in the Tharrawaddy forest division. The objective of this decision was to expand the production of teak and other valuable timber species by converting the then uneven-aged understocked forest into a fully-stocked forest containing a regular series of even-aged stands over one rotation. The annual yield was set at 2,400 trees. However, in 1924 this figure was increased to 3,952 when the yield was calculated using a Burmese version of Von Mantel's formula ${ }^{5}$ which assumed a particular basal area is produced over a rotation of 120 years (GovT. of BuRma 1928). An average of 1,266 trees were girdled each year from 1918 to 1923 . This was increased to an average of 3,721 trees per year between 1924 and 1927 (Govr. of Burma 1963-64).

The 1928 working plan

In 1928 a new working plan was introduced. Its objective was to improve the forest and maintain a sustained yield using the former selection system. The girdling scheme proposed for the 30 years to 1958 was based on data from 1912-13.

Using the Burmese version of Von Mantel's formula, the annual yield was fixed at 3,190 trees, but domestic and international events disrupted the implementation of this girdling schedule. The events included: the farmers' revolt of 1930, financial stringencies in the early 1930s and World War II from 1939 to 1945. Soon after Myanmar gained its independence in 1948, internal civil unrest broke out and continued for many years. As a result, no girdling could be conducted between 1948 and 1955. In some reserved forests, girdling was done for only 9 years. The data available for the period from 1928 to 1948 show that 21,954 trees were taken (Govt. of Burma 1946-47). However, based on data in the 1928 Working Plan the author estimates that in fact about 18,000 more trees might have been girdled.

The 1946 working plan

As described above, the 1928 working plan was not able to be implemented completely. Two preliminary working plans were prepared in 1936 and 1938, but they were never officially approved and remained in draft form until the working plan of $1946-47$ was introduced. It was intended that this plan would end in 1962. Teak girdling began in 1956 with a new permitted yield limit based on the intensity of previous girdlings. Many compartments left ungirdled from the previous 1928 plan were allocated for girdling in the seven years from 1956 to 1962 . Thus the permitted annual yield for this 7-year period was set at 8 , 241 trees- much higher than would have been calculated normally (Govt. of BuRma 1946-47). The available data for 1956 to 1962 shows that 28,683 trees were girdled in this period (Govr. of Burma 1946-47). However, the author also estimates that about 40,000 more trees might have been girdled.

\section{The 1963-64 working plan}

This plan was prepared to cover the ten-year period from 1963-64 to 1973-74. A thirty-year felling cycle was proposed with a girdling schedule that extended from 1963 to 1993 . An annual permitted yield of 3,100 trees was 
calculated using a method similar to that of the 1946 plan. The permitted yield was recalculated in 1978-79 and allowed the girdling of 5,290 trees. However the former annual yield limit of 3,100 per year was reintroduced in 1980-81. Girdling fluctuated greatly over this 30-year period, as shown in Fig. 2. The number of trees girdled in 17 of the 30 years exceeded the permitted yield. A total of 152,924 trees were girdled, and this included the felling of 6 , 387 green teak trees ${ }^{6}$, giving an average annual girdling rate of 4,885 trees per year, against the working plan's limit of 3,100 trees per year. For the whole period from 1856 to 1993 , it was estimated that an annual average of 3,100 trees was taken from these reserved forests.

\section{A HISTORICAL COMPARISON OF TEAK GROWING STOCK}

An understanding of the effect of this teak selection system on the condition of the region's forests can be gained from an examination of available growing stock data (trees per 100 acres). A comparison will be made of data from three different periods: 1912-13, 1982-86, and 1994. However, the differences between the data bases need to be recognized. The 1912-13 survey used estimates of the growing stocks based on a sampling method that covered $28 \%$ of the whole reserved forest area, excluding planted areas. Compartments covering a variety of forest types were selected and sampled, and the collected data were then used to estimate the condition of the stock in adjacent compartments. The 1982-86 and 1994 surveys used systematic sampling techniques that covered all forest areas. Sample plots were located in natural forests at intervals of 3,300 yards and each plot covered 2.59 acres. It should be also noted that the classification of girth classes was changed in 1982-86 (see Tables 3, 4, and 5). There was also a reorganization of forest areas during the early 1980 s. This resulted in forestry and civil administrative areas sharing the same boundaries, with some reserved forests being divided between two townships. Strictly speaking, therefore, the growing stock data for 1912-13 are not comparable with those of 1982-86 and 1994. Nevertheless, the average stocking rates indicate some very interesting changes in stand structure, and these changes are seen in Tables 3, 4, and 5 .

A comparison of Tables 3 and 4 shows that the number of trees with a girth of 3 feet or more in 1982-86 was about 1.3 times that in 1912. Similarly the number of trees with a girth of 6 feet or more in 1982 was 2.4 times the number in 1912. A decline is only observed in the lower girth class which shows that there had been a lack of regeneration. The Forest Department found the same situation in many forest areas across Myanmar (Forest DePART. MENT 1990). KEH (1993) also found a similar situation in the Zamayi reserved forests of Pegu hill forests. Tables 4 and 5 show important changes between 1982-86 and 1994. The total growing stock for all girth classes declined by about $50 \%$ or more over the 12 years. This decline in growing stock is quite serious and occurred in spite of the fact that the reported actual harvest from 1982 to 1993 was on average about 3,200 trees a year, close to the permitted yield level (Forest Department 1995a).

\section{POSSIBLE REASONS FOR THE POOR REGENERATION AND THE DEGRADATION OF TEAK STOCKS}

The poor regeneration can be explained by inadequate improvement fellings, especially between 1942 and 1957 (Chein HoE 1969). The social and political situation of Tharrawaddy for the 30 to 50 years prior to 1980 prevented regular girdling, logging and adequate improvement fellings. The other factor that likely contributed to the low numbers of teak trees in smaller girth classes was illegal felling. Small teak trees are of a size of that can be easily removed by some villagers on bullock carts for either sale or for use in their houses. Both Myanmar's natural forests and plantations were devastated during World War II and subsequent periods of civil unrest (LwIN 1967). In Tharrawaddy forest division, a total of 7,100 forest offences were committed between 1946-47 and 1972-73, of which 5,311 were for unauthorized fellings (Govt. of Burma 1963-64).

The drastic fall in teak stocks between 1982 and 1994 can be explained by plantation establishment and illegal logging. Plantation establishment increased after 1980 and a total of 23,000 acres were planted in these forests between 1982 and 1993. Generally, plantations had to be established in degraded forests. However, in 1982 the Forest Department required plantations to be established in blocks of 200 acres or larger, so it was inevitable that natural forests were sometimes included in blocks chosen for planting. The Forest Department allowed plantation establishment in some natural forests where there was teak and/or "Group one" species with a girth of 2 feet or more. Thus, it can be assumed that removal of teak trees from plantation sites was probably part of the reason for this reduction in growing stock. However, illegal logging is the most likely reason. KeH and KyAw (1995) state that illegal logging and the selling of teak and other valuable hardwoods probably account for the major decline in the growing stock of Myanmar's forest, especially in accessible areas. Tharrawaddy is situated in an easily accessible area, only 125 $\mathrm{Km}$ from Rangoon.

\section{CONCLUSION}

Since the late 1800 s, Myanmar has been attempting to apply a philosophy of sustained timber yield to the management of its native teak forests, but it has learnt that it is complex and difficult to implement. Even though it has faced many obstacles in the management of these forests 
for sustainable wood production, the Forest Department yield forest management. Myanmar's persistence in apply-

Table 3 Teak growing stock (trees per 100 acres) - 1912-13 estimation

\begin{tabular}{|l|c|c|c|c|c|c|c|}
\hline Reserve & $\begin{array}{c}\text { Area (ac)/ } \\
\text { Girth class }\end{array}$ & $1^{\prime} 6^{\prime \prime}$ to $2^{\prime} 11^{\prime \prime}$ & $3^{\prime}$ to $4^{\prime} 5^{\prime \prime}$ & $4^{\prime} 6^{\prime \prime}$ to $5^{\prime} 11^{\prime \prime}$ & $6^{\prime}$ to $7^{\prime} 5^{\prime \prime}$ & $7^{\prime} 6^{\prime \prime} \&$ up & Total \\
\hline Minhla & 25,884 & 89 & 107 & 77 & 43 & 28 & 344 \\
Mokka & 22,425 & 110 & 124 & 83 & 38 & 24 & 379 \\
Kadinbilin & 53,216 & 113 & 120 & 94 & 47 & 27 & 401 \\
Konbilin & 15,988 & 113 & 130 & 91 & 38 & 23 & 395 \\
Thonze & 69,735 & 158 & 147 & 101 & 31 & 14 & 451 \\
\hline Total & 187,248 & 126 & 130 & 92 & 38 & 22 & 408 \\
\hline
\end{tabular}

Source: Government of Burma, 1918.

Table 4 Teak growing stock (trees per 100 acres) - 1982-86 estimation

\begin{tabular}{|l|c|c|c|c|c|c|c|}
\hline Townships & $\begin{array}{c}\text { Area (ac) } \\
\text { Girth class }\end{array}$ & $2^{\prime}-2^{\prime} 11^{\prime \prime}$ & $3^{\prime}-4^{\prime} 11^{\prime \prime}$ & $5^{\prime}-5^{\prime} 11^{\prime \prime}$ & $6^{\prime}-7^{\prime} 11^{\prime \prime}$ & $8^{\prime} \&$ up & Total \\
\hline Minhla & 45,170 & 76 & 117 & 10 & 23 & 6 & 232 \\
Letpadan & 166,070 & 56 & 106 & 88 & 139 & 50 & 439 \\
Tharrawaddy & 77,980 & 79 & 267 & 108 & 98 & 14 & 566 \\
\hline Total & 289,220 & 65 & 151 & 81 & 110 & 34 & 441 \\
\hline
\end{tabular}

Source: Forest Department, Myanmar, 1991

Table 5 Teak growing stock (trees per 100 acres) - 1994 estimation

\begin{tabular}{|l|c|c|c|c|c|c|c|}
\hline Townships & $\begin{array}{c}\text { Area (ac)/ } \\
\text { Girth class }\end{array}$ & $2^{\prime}-2^{\prime} 11^{\prime \prime}$ & $3^{\prime}-4^{\prime} 11^{\prime \prime}$ & $5^{\prime}-5^{\prime} 11^{\prime \prime}$ & $6^{\prime}-7^{\prime} 11^{\prime \prime}$ & $8^{\prime} \&$ up & Total \\
\hline Minhla & 33,430 & 8 & 23 & 8 & 3 & 5 & 47 \\
Letpadan & 169,070 & 28 & 60 & 31 & 34 & 12 & 165 \\
Tharrawaddy & 75,860 & 64 & 141 & 69 & 127 & 0 & 401 \\
\hline Total & 278,360 & 35 & 77 & 38 & 56 & 8 & 214 \\
\hline
\end{tabular}

Source: Anon, 1996 (Unpubished documents).

Notes: As explained in the text, prior to 1980 the area of forestry administration was not matched with that of civil administration. In order to match forestry and civil administrative areas, reorganization of the forest areas was done in the early 1980s. As a result, some reserved forests were divided into two parts, included in two township forest areas closely located.

In Tharrawaddy forest division, because of this re-organization, Minhla reserved forest was divided into two parts: one in Minhla township and the other in Letpadan township. Konbilin reserved forest was also divided and included in Letpadan and Tharrawaddy townships. The results of forestry inventories conducted after 1980 were shown on a township basis.

has persisted in applying such principles for nearly one and a half centuries.

The widespread use of slogans such as "forestry for sustainable development" by international development and conservation organizations, and the introduction of ITTO's guidelines on the sustainable management of natural tropical forests and tropical plantations indicate that serious efforts are being made at the regional and international levels to achieve sustained yield management of tropical wood resources. They also reflect the fact that some regions of the world have neglected basic sustained ing a sustained yield philosophy should be recognized as a historically significant effort to maintain its cover of natural forests and protect its teak resources. In theory, Myanmar's forestry working plans should be revised every 10 years. However, the plans examined in this paper were revised irregularly. As far as can be ascertained the main reasons for this irregularity were recalculations of teak growth rates and social and political changes. Clearly technical considerations alone are not sufficient to guarantee sustained yield management. Social, political, economic and administrative aspects must be considered in the devel- 
opment of long-term forest management principles and plans.

In particular, the sustained production of teak from natural forests will be difficult because of its low rate of occurrence in Myanmar's native forests. Brandis considered that planting teak in the natural forests to increase the potential for achieving sustainable production would offer considerable opportunities. Teak logs have mostly come from natural forests and the management of teak in natural forests is still being given priority. For example, the objectives for future forest management laid down in the forest policy of 1995 include: "to pursue a sound programme of forest development through regeneration and rehabilitation operations, to optimize productivity from natural forests, to recognize that plantation forestry is not a substitute for natural forest management" (GovT. OF Myanmar 1996). However, three actions should be taken immediately to counter the decline in natural regeneration and the drastic fall in teak growing stock. They are carrying out enrichment planting, prevention of illegal logging and encouraging public participation in forest management.

Enrichment planting using teak stumps should be undertaken. Teak stumps are easy to transport and can be stored almost anywhere. Their coppice shoots outgrow weeds within a year or two if the sites are tended and weeded. They thus have important advantages when compared to the planting of teak seedlings. Between 30 and 50 teak stumps per acre could be planted in the reserved forests. Enrichment planting of this number of stumps is feasible from both labour and financial perspectives. (In teak plantations managed on 80-100 year rotations, about 40-50 trees per acre are left standing after the final tending operation at 40 years).

Prevention of illegal logging is also essential. At the time of British rule, strong punishment was meted out to those who breached the forest laws. Also, reserved forests were created in the plain areas to supply timber to local inhabitants whose population was much less than now. Such action helped protect the natural forests from being destroyed. The nation's population has grown and the plain forests have been converted to agricultural land or townships, so the population pressure on the remaining natural forests has increased. Timber products have enjoyed higher prices since 1989 when the private sector was allowed to reenter the timber trade and this has also encouraged illegal logging.

Public participation in forest management is a prerequisite for solving these problems. And in 1995, the government of Myanmar issued a "Community forestry instruction" encouraging local people to participate in forest management planning and implementation (Forest DEPARTMENT 1995b). Local people are now able to use reserved natural forests and plantations established for local needs on a sustainable basis. The Forest Department provides people with seedlings and explains the most appropriate methods for both plantation establishment and initial enrichment plantings. As well, it will not levy a royalty on forest products extracted from community forests for domestic use or for sale in the local area. These policy measures are expected to reduce the population pressure on forests and discourage illegal logging. If action can be taken on the three issues, the future for Myanmar's teak production will look for a more positive.

\section{LITERATURE CITED}

Brandis, D., (1896): The Burma teak forest. Garden and Forests, Vol. IX, New York, 1-32.

Chein Hoe., (1969): Teak of Myanmar (Text in Myanmar language), Sapaybeikman, Rangoon, 374pp

Diokno, M. S. I., (1983): British firms and the economy of Burma, with special reference to the rice and teak industries, 1917-37. Ph.D. Thesis, London University, 297pp

Forest Department, (1990): Forest management in Myanmar, 26pp

Forest Department, (1991): Forest Resource Data, Bago Division, Forest Resource Division, National Forest Management and Inventory Project, UNDP/FAO: Mya/85/003, Yangon, Myanmar, 37pp

Forest Department, (1995a): Comparison of actual and prescribed girdlings and green marking (yield trees), Teak selection working circle, Planning and Statistics Division, 69pp

Forest Department, (1995b): Community forestry instructions, Yangon, Myanmar, 17pp

Forest Department, (1996): Forestry fact sheets, 1996. Yangon, Myanmar, 38pp

Government of Burma, (1918, 1919, 1928, 1946-47 to 1962-63, and 196364 to 1972-73): Working Plans for Tharrawaddy Forest Division, Forest Department, Myanmar.

Government of Myanmar, (1996): Myanmar Forest Policy, 1995, Policy Statement, $12 \mathrm{pp}$

$\mathrm{KEH}, \mathrm{K}$., (1993): The problems of natural regeneration of teak in the lower reaches of Bago Yoma: particularly in the south Zamayi and north Zamayi reserved forests. Forestry Science Research Paper, Forest Department, Myanmar, 10pp

$\mathrm{KEH}_{\mathrm{EH}}$ K. and KYAW, S., (1995): A general study of the growing stock of teak in the Bago Yoma; Some suggested redress. A paper to be presented to the teak symposium conducted under Myanmar-Japan Technical Cooperation Programme, Yangon, Myanmar, 12pp

Lwis, T., (1967): Thit taw yadana: Treasure of the forests (Text in Myanmar language), Sapaybeikman, Rangoon, 374pp

Morehead, F. T., (1944): The forests of Burma. Burma Pamphlets, No. 5 , London, Longmans, $67 \mathrm{pp}$

Osmaston. F. C., (1968): The management of forests, George Allen and Unwin Ltd., 384pp

\section{NOTE}

1) In Myanmar, the spellings of some towns and rivers, etc., have been changed. The words in parentheses show the old spelling of names as used in this paper; Bago (Pegu), Pyay (Prome). Ayeyarwady (Irrawaddy), Taung gu 
(Taungoo). As this paper is concerned with the historical context, the old names are used for the sake of consistency. 2) Girdling means killing a tree with a broad circular cut through its bark and into the sapwood. Teak trees left standing for three years after being girdled dry evenly and can thus be floated down river. This produces a good quality timber and reduces extraction costs. Most teaktrees in Myanmar are harvested three years after girdling. Teak trees of under exploitable girth are also girdled if they are unlikely to survive up to next felling cycle (30 years). It is said that the number of such trees consisted of about $10 \%$ of total girdled trees.

3) This is equivalent to a stem diameter of 22.9 inches or $58.2 \mathrm{~cm}$. Although the minimum girth limit was set at 6 feet in girth at 6 feet in height, the actual girdling was done to those trees of 7 feet in girth at 6 feet in height in Thonze forests in 1857. It is mentioned that the girth limit was raised to 7 feet measured at 6 feet from the ground (Govr, of Burma 1946-47). The present measurent of exploitable girth at 7 feet 6 inches in moist forest and 6 feet in dry forests measured at 4 feet 6 inches in height have been begun in 1930 (Chein Hoe 1969).

4) Group one includes Pyinkado (Xylia dolabriformis), Padauk (Pterocarpus macrocarpus), Thingan (Hopea odorata), Thitya (Shorea oblongifolia), Ingyin (Pentacme siamensis) and Tamalan (Dalbergia oliveri).
5) The application of Von Mantel's formula in selection systems might produce conservative yield estimates. Osmas. TON (1968) explains that the formula has frequently been used for irregular forests that are extensively managed e.g. in India and Burma where the yield has been confined mainly to those comparatively large trees above a size limit that corresponds to the exploitable age. In such a situation the yield will be conservative.

Von Mantel's formula is shown in Osmaston (1968) as,

$$
A Y=\frac{2 A G}{R}
$$

Where,

$A Y=$ Annual Yield, $A G=$ Actual Volume of Growing stock, and $R=$ Rotation

The Burmese version of this formula was

$$
A B A=\frac{T B A}{R / 2 x\left(1-r^{2} / R^{2}\right)}
$$

Where,

$A B A=$ Annual Yield in Basal Area, $T B A=$ Total Basal Area, $R=$ Rotation, and $r=$ number of years taken to achieve the smallest girth measured in all sample data.

6, Harvesting teak trees without conducting any girdling.

(Received 2 February 1998)

(Accepted 9 March 1998) 